\title{
AN EXPLORATORY INVESTIGATION OF VISITOR MOTIVATIONS TO THE BARBERTON - MAKHONJWA GEOTRAIL, SOUTH AFRICA
}

\author{
Leane GROBBELAAR \\ Department of Tourism Management, Tshwane University of Technology, \\ Mbombela (Nelspruit), South Africa, e-mail: GrobbelaarL@tut.ac.za \\ Samantha BOUWER \\ Department of Tourism Management, Tshwane University of Technology, \\ Mbombela (Nelspruit), South Africa, e-mail: BouwerS@tut.ac.za
}

\section{Uwe P HERMANN*}

Centre for Sustainable Tourism, Department of Tourism Management, Tshwane University of Technology, Private Bag X680, Pretoria, o004, e-mail: hermannup@tut.ac.za

\begin{abstract}
Citation: Grobbelaar, L., Bouwer, S., \& Hermann, U.P. (2019). AN EXPLORATORY INVESTIGATION OF VISITOR MOTIVATIONS TO THE BARBERTON - MAKHONJWA GEOTRAIL, SOUTH AFRICA. GeoJournal of Tourism and Geosites, 25(2), 283-292. https://doi.org/10.30892/gtg.25101-359
\end{abstract}

\begin{abstract}
Geotourism is a relatively new tourism niche, representing a distinctive form of nature-based tourism. South Africa has a wealth of geological resources, many of which form the basis for tourism attractions within the country, but limited research has been conducted on the actual geotourism market. By means of a questionnaire informed by the Self Determination Theory, this study aimed to understand the motivations of visitors to the recently developed Barberton Makhonjwa Geotrail in South Africa. The main findings revealed five main motivators including, to escape, for learning and novelty, to participate in activities and networking, for fun, and for personal importance. These findings have important implications for product development and marketing.
\end{abstract}

Key words: Geotourism, geotrail, visitor motivation, Self-Determination Theory

\section{INTRODUCTION}

Geotourism is gaining considerable momentum as a focus of academic debate (Ruban, 2015:1). As a result, definitions of geotourism are continually evolving (Hose, 1995; Dowling \& Newsome, 2006; Sadry, 2009; Hose, 2012). The key tenets of geotourism emerging from such definitions include 'geology', 'sustainability' and 'education'. Indeed, these tenets are succinctly embraced in the definition provided by

\footnotetext{
* Corresponding author
} 
Dowling and Newsome (2006:3) who refer to geotourism as tourism that is geologicallybased, conservation-focused, involving "an understanding of earth sciences through appreciation and learning". Although a relatively new term, geotourism is certainly not a new form of tourism. People have travelled for centuries with the purpose of making connections with the environment and the geological features within it. Such geological features are numerous and diverse including mountains, volcanic and water features, mud volcanoes, salt domes, caves, sinkholes, kavirs and deserts, and erosion columns (Amrikazemi \& Mehrpooya, 2006). In addition, Sadry (2009) also alludes to sites of interest that are a result of human intervention, such as mines, road cutting sites and stone houses, and adventure-based geosites. To date, academic contributions on geotourism have tended to centre on the development of geotourism products (Zouros, 2010; Farsani et al., 2011; Allan, 2016), and specifically geotrails (Wrede \& MúggeBartolović, 2012; Norrish et al., 2014). Similarly, studies pertaining to the impacts of tourism on geosites are also abundant (Hose, 2007; Burne \& Chapple, 2008; King, 2010; Farsani et al., 2011). Other avenues of investigation include promotional strategies for geotourism sites (Farsani et al., 2011) and geo-education (Farsani et al., 2017).

However, as with all tourism attractions, the success of geotourism sites requires an analysis of the market, thus a better understanding of demand. Although progress has been made in terms of the development of geotourist demographic profiles (King, 2010) and motivational typologies (Hose, 2007; Kim et al., 2008; Mao et al., 2009; Hurtado et al., 2014), literature still remains somewhat scant, with a paucity of studies concerning geotrails in particular. Furthermore, Ruban (2015) also observes an absence of inquiry in South Africa, and indeed the African continent as a whole, despite its wealth of geological heritage. Hence, the purpose of this study is to understand the motivations of visitors to engage in a geotourism experience at the Barberton Makhonjwa Geotrail in South Africa.

\section{Literature Review}

The question of what motivates people to travel is fundamental to tourism marketing and development. Motivation theories are numerous (Cohen, 1972; Plog, 1974; Dann, 1981; McIntosh et al., 1995). Indeed, they play an essential role in understanding the reasons why tourists travel, in addition to the types of activities they engage in whilst being away from home (Allan et al., 2015). Motivation is a significant, yet complicated part of tourism demand and thus a key research focus in tourism. It has become increasingly important to re-evaluate tourist motivations over the past decade due to global economic integration, continuously improving communication, and rapid technological innovation (Harrill \& Potts, 2002). Although the topic of motivation has been extensively studied in tourism, the discussion on motivation in a geotourism context is limited. Table 1 provides a summary in this regard.

Table 1. Geotourism motivation studies

\begin{tabular}{|l|l|}
\hline \multicolumn{1}{|c|}{ Contributors } & \multicolumn{1}{c|}{ Outcome } \\
\hline Hose (2007) & $\begin{array}{l}\text { Identified and differentiated between the 'dedicated geo-tourist' and } \\
\text { the 'casual geo-tourist'. }\end{array}$ \\
\hline $\begin{array}{l}\text { Kim, Kim, Park, and } \\
\text { Guo (2008) }\end{array}$ & $\begin{array}{l}\text { Developed four clusters of geotourists; escape-seeking, knowledge / } \\
\text { novelty seeking; novelty-seeking and socialisation. }\end{array}$ \\
\hline $\begin{array}{l}\text { Mao, Robinson, and } \\
\text { Dowling (2009) }\end{array}$ & $\begin{array}{l}\text { Focused solely on geoscientists, who travelled alone and for the } \\
\text { purpose of increasing knowledge. }\end{array}$ \\
\hline $\begin{array}{l}\text { Hurtado, Dowling, and } \\
\text { Sanders (2014) }\end{array}$ & $\begin{array}{l}\text { Developed a geotourist typology model adapted from Mckercher's } \\
\text { cultural typology model. Types included: incidental, accident, } \\
\text { serendipitous, intentional and purposeful geotourist segments. }\end{array}$ \\
\hline $\begin{array}{l}\text { Allan, Dowling, and } \\
\text { Sanders (2015) }\end{array}$ & $\begin{array}{l}\text { Adapted the Self Determination Theory using the tenets of intrinsic } \\
\text { motivation, extrinsic motivation and amotivation. }\end{array}$ \\
\hline
\end{tabular}


Hose (2007) proposed two main typologies within geotourism to include the 'dedicated geotourist' and the 'casual geotourist'. The former places importance on personal education / intellectual gain and enjoyment, whilst the latter rather gives precedence to pleasure. Kim et al., (2008) sought to investigate motivations of geotourists to a cave in Korea. Based on a cluster analysis, their study proposed four categories of motivation including; escape seeking, knowledge and novelty seeking, novelty seeking, and socialisation. Within each cluster, the study further sought to draw up a demographic profile of such visitors, which also included elements of visitor satisfaction, preferences, and beliefs regarding cave resources. Mao et al., (2009) adopted a more targeted approach, exploring the motivations of geoscientists, specifically. Their research concluded that such tourists travelled alone and, unsurprisingly, for the purpose of increasing knowledge. Hurtado et al., (2014) applied an existing cultural tourism typology model proposed by McKercher (2002) in a geotourism context. Using a sample of geotourists visiting the Crystal Cave in Western Australia, their study concluded that such a model was indeed applicable to that of geotourism but with slight modifications (Table 2).

Table 2. Geotourism typology model (Source: Hurtado et al., 2014:612).

\begin{tabular}{|l|c|c|c|c|c|}
\hline Motivation & \multicolumn{2}{|c|}{ Low } & Medium & High & Very High \\
\hline Geotourist & $\begin{array}{c}\text { Incidental } \\
\text { Geotourst }\end{array}$ & $\begin{array}{c}\text { Accidental } \\
\text { Geotourist }\end{array}$ & $\begin{array}{c}\text { Serendipitou } \\
\text { s Geotourist }\end{array}$ & $\begin{array}{c}\text { Intentional } \\
\text { Geotourist }\end{array}$ & $\begin{array}{c}\text { Purposeful } \\
\text { Geotourist }\end{array}$ \\
\hline Experience & Negative & \multicolumn{5}{c|}{ Positive } \\
\hline
\end{tabular}

The 5-component typology represents the spectrum of geotourists according to their motivation and experience. Essentially, at one end of the spectrum is the 'purposeful geotourist' who is highly motivated with the primary purpose of visitation to gain knowledge and insight. This individual has a positive experience.

In contrast, at the other end of the spectrum is the 'incidental geotourist' who exhibits a low level of motivation with geotourism playing no meaningful role in destination choice, and whose experience is somewhat negative. Table 3 details the descriptors of each geotourist type within the continuum.

Table 3. Descriptors of Geotourist Types (Source: Hurtado et al., 2014:612)

\begin{tabular}{|c|c|}
\hline Type of Geotourist & Descriptors \\
\hline $\begin{array}{l}\text { Purposeful } \\
\text { Geotourist }\end{array}$ & $\begin{array}{l}\text { Very high motivation / positive experience } \\
\text { - The main motivation for travel is to visit a geosite; } \\
\text { - Has a positive experience based on their interest in the geosite; } \\
\text { - Desires to learn more. }\end{array}$ \\
\hline $\begin{array}{l}\text { Intentional } \\
\text { Geotourist }\end{array}$ & $\begin{array}{l}\text { High motivation / positive experience } \\
\text { - Motivation is influenced by the geo-site; } \\
\text { - Additional motivations are also present; } \\
\text { - They have a positive experience and enjoy the information delivery. }\end{array}$ \\
\hline $\begin{array}{l}\text { Serendipitous } \\
\text { Geotourist }\end{array}$ & $\begin{array}{l}\text { Medium motivation / positive experience } \\
\text { - Geotourism plays a moderate role in the decision to visit a geosite; } \\
\text { - Once on-site, they engage in a positive experience. }\end{array}$ \\
\hline $\begin{array}{l}\text { Accidental } \\
\text { Geotourist }\end{array}$ & $\begin{array}{l}\text { Low motivation / positive experience } \\
\text { - Motivation is not influenced by geotourism; } \\
\text { - This tourist may not even be aware of the geosite prior to visitation; } \\
\text { - Once on-site, the experience encountered is positive. }\end{array}$ \\
\hline $\begin{array}{l}\text { Incidental } \\
\text { Geotourist }\end{array}$ & $\begin{array}{l}\text { Low motivation / negative experience } \\
\text { - Geotourism plays no meaningful role in destination choice; } \\
\text { - The experience encountered is negative. }\end{array}$ \\
\hline
\end{tabular}


The final example of a geotourism motivation study highlighted in Table 1 is that by Allan et al., (2015) who asserted that the Self-Determination Theory (SDT) presents the most appropriate method for investigating geotourists' motivation in undertaking a geotourism experience, given that it incorporates a range of motivation theories (Cognitive Evaluation Theory, Organismic Integration Theory, Causality Orientations Theory and Basic Needs Theory) which emphasise the type of motivation and not only the total amount of motivation. The most significant distinction in SDT is made between 'autonomous motivation' and 'controlled motivation'. Autonomous motivation comprises both intrinsic motivation and the types of extrinsic motivation in which people have identified and integrated an activity's value into their sense of self (Deci \& Ryan, 2008). Allan (2011) further alludes to autonomous motivation comprising the desire to act and participate in an activity with a full sense of 'choice' because it is interesting and exciting. When a person is autonomously motivated, he / she experiences self-endorsement of his / her actions, or volition (Deci \& Ryan, 2008). In contrast, controlled motivation consists of both external regulation and introjected regulation. With external regulation, a person's behaviour is a function of external possibilities of reward or punishment.

In the case of introjected regulation, the regulation of the action has been partially internalised and aspects such as an approval motive, avoidance of shame, contingent selfesteem and ego-involvements motivate behaviour (Deci \& Ryan, 2008). Controlled motivation, according to Allan (2011), can be summarised as a sense of selection based on pressure and constraints. As a result, controlled people experience pressure to think, feel, or behave in a specific way. In summary, SDT suggests that, "behaviours can be characterised in terms of the degree to which they are autonomous versus controlled" (Gagne \& Deci, 2005:334). SDT further posits a self-determination continuum which ranges between three types of motivation; intrinsic, extrinsic and amotivation. When people participate in an activity because they find it interesting, fun and/or challenging, and the activity results in spontaneous satisfaction, the motivation for participation, is intrinsic in nature (Ryan \& Deci, 2000:56). Gagne and Deci (2005:334) elaborate, claiming that when people are intrinsically motivated to do something, they act with selfdirection and autonomy and are free from external forces. Intrinsic motivation measures include knowledge gain, enjoyment, escape from daily routine, relaxation, excitement, friendship, and a sense of wonder (Allan, 2011:56). Extrinsic motivation, on the other hand, is when a person engages in an intentional behaviour with the purpose to earn external rewards or avoid punishment (Allan, 2011). Extrinsic motivation measures include an analysis of the social, cultural and recreational benefits, importance to visit the site, the need to participate in order to be happy, the need of being occupied with activities, for status reasons, and because pressure exists to participate. Finally, amotivation refers to a lack of motivation and usually occurs when people do not realise that the outcome or reward is subject to their action (Deci \& Ryan, 2008). The utility of this holistic approach to motivational analysis (i.e. the combination of various motivational theories), thus provided the rationale for the adoption of the SDT as a framework for understanding visitor motivations to the Barberton Makhonjwa geotrail.

\section{STUDY AREA}

The Barberton Makhonjwa Geotrail is one of South Africa's most recently developed geotourism attractions. Forming part of the Barberton Makhonjwa Mountain Lands, the area is otherwise referred to as the Barberton Greenstone Belt and contains some of the oldest, well preserved rocks on earth, with the physical and chemical characteristics remaining substantially unaltered since their original formation (Ferrar \& Heubeck, 2013:ix). The geotrail showcases some of the oldest rock formations (3.2-3.57 
billion years) on earth dating back to the Archaean period of earth's history. In addition, some of the oldest preserved fossils of cyanobacteria, the foundation of life on earth, have been found here (BATOBIC, 2018). Besides its unique geology, the Region also supports a rich plant, animal and birdlife, and hence is one of South Africa's 20 biodiversity hotspots. Other cultural features include the scars of historical mining, stone-age shelters and artefacts, and ancient ochre mines (Ferrar \& Heubeck, 2013). Indeed, the site is so important that UNESCO designated it a world heritage site in July 2018 (UNESCO, 2018).

Commencing in Barberton (Figure 1), the route follows the R40, extending $38 \mathrm{~km}$ towards the Bulembu Border Gate with Swaziland. There are 11 designated sites along the route which represent different geological phenomena. These sites provide interpretive facilities to visitors to showcase the landscapes and geological features along the route. The majority of the sites have designated parking and interpretation panels, with many offering scenic viewpoints. However, there are currently no amenities along the route that promote visitor spend (such as retail outlets).

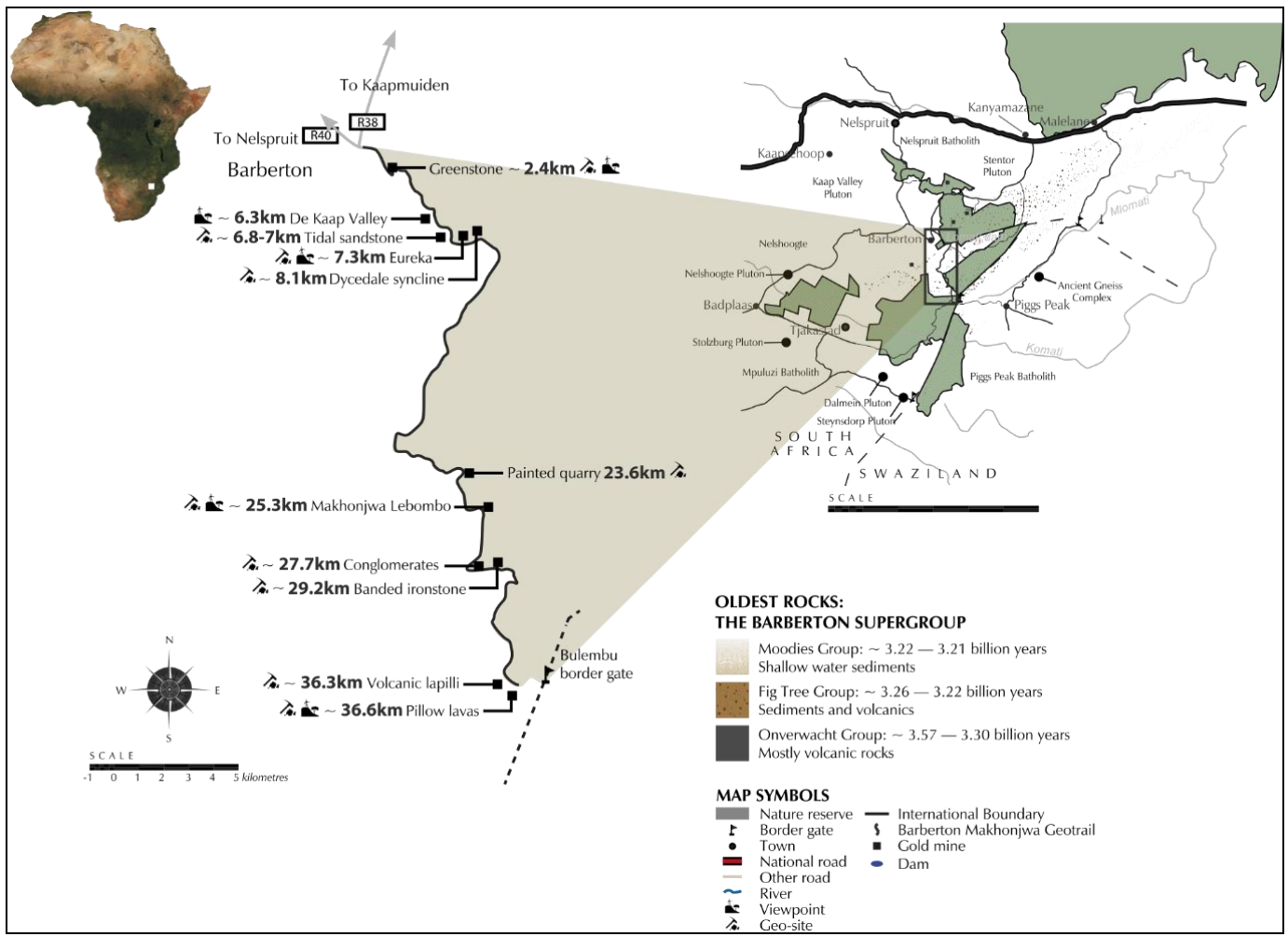

Figure 1. Barberton-Makhonjwa Geotrail (Source: BATOBIC, 2018)

\section{METHODOLOGY}

This study was quantitative and exploratory in nature utilising a survey research design. The target audience was 'intentional' visitors to the Barberton Makhonjwa Geotrail, as opposed to visitors simply using the route to access the border post to Swaziland. Due to the absence of a sampling frame, convenience sampling was utilised to determine a sample of 70 respondents. The questionnaire was adapted from Allan et al. (2015) and formed two sections. The purpose of the first section was to elicit demographic information from the respondents including age, gender, nationality, and place of 
residence. The second section was designed to elicit visitor motivations. Questions were framed around the key constructs of the Self Determination Theory; extrinsic motivation, intrinsic motivation and amotivation. Using a five point Likert scale, ranging from 1 (strongly disagree) to 5 (strongly agree), respondents had to indicate their level of agreement for each motivational item listed under each key construct.

On-site self-completion questionnaires formed the primary data collection tool, and were administered over a 3-month period (April - June 2016). Trained fieldworkers were on-site to issue, clarify and collect the questionnaires. The majority of the questionnaires were completed at strategic locations on the trail such as viewpoints and parking areas. Data was captured on MS Excel and statistical analyses were performed in two parts. Firstly, a descriptive analysis was conducted to determine the frequencies of both demographic and motivator variables. Secondly, an exploratory factor analysis (EFA) was conducted on the motivator variables in order to identify the main motivators.

\section{RESULTS}

The results of the study are presented in two main parts. Descriptive results pertaining to demographics and Likert scale ratings are firstly presented, followed by the results of an EFA.

\section{Descriptive results}

In terms of demographics, the majority of respondents were male (60\%) compared to females (40\%). Respondents were primarily in the age bracket of 25-54, which made up a total of $64.4 \%$ of respondents. Other age groups included 18- 24 years (14.3\%), 55-64 (12.9\%), 65-74 (7.1\%) and $75^{+}$at $1.4 \%$. In terms of nationality, the majority of respondents were South African (77.1\%).

TABLE 4. Descriptive results of visitor motivations ( ${ }^{*}$ Standard Deviation)

\begin{tabular}{|c|c|c|c|c|c|c|c|}
\hline \multirow{2}{*}{\multicolumn{2}{|c|}{ Statement }} & \multirow{3}{*}{\begin{tabular}{|l|} 
Strongly \\
disagree
\end{tabular}} & \multirow{3}{*}{\begin{tabular}{|c|}
$\mathbf{2 .}$ \\
Disagree \\
1.4
\end{tabular}} & \multirow{3}{*}{\begin{tabular}{|c|}
$\mathbf{3 .}$ \\
Neutral \\
7.5
\end{tabular}} & \multirow{3}{*}{\begin{tabular}{|c|}
$4 \cdot$ \\
Agree \\
46.4 \\
\end{tabular}} & \multirow{3}{*}{\begin{tabular}{|c|}
$\mathbf{5 .}$ \\
$\begin{array}{c}\text { Strongly } \\
\text { agree }\end{array}$ \\
44.9 \\
\end{tabular}} & \multirow{2}{*}{$\begin{array}{c}\text { Mean } \\
/ \text { Sd }^{*}\end{array}$} \\
\hline & & & & & & & \\
\hline 1 & To learn new things & & & & & & $4.35 / .682$ \\
\hline 2 & To increase my knowledge & & 2.9 & 17.4 & 39.1 & 40.6 & $4.17 / .822$ \\
\hline 3 & To relax and rest & & 0 & 11.6 & 27.5 & 58.0 & $4.38 / .909$ \\
\hline 4 & To refresh my mental and physical state & & 4.3 & 18.8 & 23.2 & 49.3 & $4.09 / 1.121$ \\
\hline 5 & To escape from the daily life routine & & 2.9 & 8.7 & $33 \cdot 3$ & 50.7 & $4.23 / 1.031$ \\
\hline 6 & It is exciting & & $\mathrm{O}$ & 7.2 & 31.9 & 60.9 & $4.45 / .632$ \\
\hline 7 & To have fun & & 1.4 & 7.2 & 30.4 & 60.9 & $4.51 / .699$ \\
\hline 8 & $\begin{array}{l}\text { To meet people with similar } \\
\text { interests and hobbies }\end{array}$ & & 8.7 & 39.1 & 24.6 & 21.7 & $3.48 / 1.106$ \\
\hline 9 & To travel with friends and my family & 5.7 & 1.4 & 5.7 & 28.6 & 58.6 & $4.33 / 1.059$ \\
\hline 10 & Because it is an exotic place & 2.9 & 5.7 & 20.0 & 32.9 & 38.6 & 3.99/.1.042 \\
\hline 11 & To explore new places & 1.4 & & 5.8 & 14.5 & 75.4 & $4.59 / .846$ \\
\hline 12 & $\begin{array}{l}\text { Because it has many social, cultural } \\
\text { and recreational advantages for me }\end{array}$ & o & 8.7 & 26.1 & 34.8 & 30.4 & $3.87 / .954$ \\
\hline 13 & $\begin{array}{l}\text { Because I believe it is personally } \\
\text { important to me to travel to the site }\end{array}$ & 1.4 & $4 \cdot 3$ & 23.2 & 30.4 & 40.6 & $4.04 / .977$ \\
\hline 14 & $\begin{array}{l}\text { In my life I need this type of tourism } \\
\text { activity to be happy }\end{array}$ & 1.4 & 5.8 & 20.3 & 31.9 & 40.6 & 4.04/.992 \\
\hline 15 & I must be occupied with activities & 2.9 & 5.9 & 30.9 & 35.3 & 25.0 & $3.79 / 1.002$ \\
\hline 16 & To show others that I am a distinct person & 17.1 & 12.9 & 31.4 & 17.1 & 21.4 & $3.13 / 1.361$ \\
\hline 17 & $\begin{array}{l}\text { Because my family and friends tell } \\
\text { me to do this activity }\end{array}$ & 28.6 & 17.1 & $24 \cdot 3$ & $15 \cdot 7$ & $14 \cdot 3$ & $2.70 / 1.408$ \\
\hline
\end{tabular}


International respondents (20\%) were predominantly from Germany, Switzerland and Belgium. In terms of local travellers, the majority resided in Mbombela (Nelspruit) (32.9\%) followed by Barberton (27.1\%). This indicates that over half the respondents resided in areas within a $50 \mathrm{~km}$ radius of the research area. Respondents were requested to rate 17 items related to visitor motivations on a Likert scale of 1 to 5 . On this Likert scale, 1 represented strongly disagree while 5 represented strongly agree. The items on the scale represented the three SDT categories of motivation (intrinsic, extrinsic- and amotivation). The results are presented as percentages in Table 4 (with the exception of the mean and standard deviation). From the findings presented in Table 4 it is evident that respondents rated the following five main individual motivator variables as the highest; 'to explore new places', 'it is exciting', 'to have fun', 'to relax and rest' and 'to learn new things'. These results provide an insight into individual motivators. For a more inferential view of these motivators, an EFA was conducted, the results of which are presented in the following section.

Table 5. Results of EFA

\begin{tabular}{|c|c|c|c|c|c|c|}
\hline \multirow{2}{*}{ Travel motivation } & \multirow{2}{*}{\begin{tabular}{|c|}
$\begin{array}{c}\text { Compo } \\
\text { - nent }\end{array}$ \\
F1 \\
\end{tabular}} & \multirow[b]{2}{*}{ F2 } & \multirow[b]{2}{*}{ F3 } & \multirow[b]{2}{*}{ F4 } & \multirow[b]{2}{*}{ F5 } & \multirow[b]{2}{*}{ F6 } \\
\hline & & & & & & \\
\hline & Escape & $\begin{array}{l}\text { Family and } \\
\text { friends }\end{array}$ & $\begin{array}{c}\text { Learning } \\
\text { and novelty }\end{array}$ & $\begin{array}{c}\text { Activities and } \\
\text { networking }\end{array}$ & Fun & $\begin{array}{c}\text { Personal } \\
\text { importance }\end{array}$ \\
\hline Cronbach Alpha & 0.730 & $\mathbf{0 . 3 4 0}$ & $\mathbf{0 . 5 5 1}$ & 0.651 & 0.753 & 0.677 \\
\hline Mean & 4.23 & 3.52 & 4.28 & 3.60 & 4.53 & 3.96 \\
\hline Standard deviation & 2.183 & 1.234 & 0.844 & 1.110 & 0.661 & 0.959 \\
\hline To relax and rest & 0.814 & & & & & \\
\hline $\begin{array}{l}\text { To refresh my mental and } \\
\text { physical state }\end{array}$ & 0.821 & & & & & \\
\hline $\begin{array}{l}\text { To escape from daily life } \\
\text { routine }\end{array}$ & 0.437 & & & & & \\
\hline To learn new things & & & 0.405 & & & \\
\hline To increase my knowledge & & & 0.358 & & & \\
\hline To explore new places & & & 0.818 & & & \\
\hline Because it is an exotic place & & & -.277 & & & \\
\hline It is exciting & & & & & -0.817 & \\
\hline To have fun & & & & & -0.906 & \\
\hline $\begin{array}{l}\text { Because it has many social, } \\
\text { cultural and recreational } \\
\text { advantages for me }\end{array}$ & & & & & & 0.769 \\
\hline $\begin{array}{l}\text { Because I believe it is } \\
\text { personally important to me } \\
\text { to travel to the site }\end{array}$ & & & & & & 0.826 \\
\hline $\begin{array}{l}\text { In my life I need this type of } \\
\text { tourism activity to be happy }\end{array}$ & & & & 0.203 & & \\
\hline $\begin{array}{l}\text { To show others that I am a } \\
\text { distinct person }\end{array}$ & & & & 0.641 & & \\
\hline $\begin{array}{l}\text { I must be occupied with } \\
\text { activities }\end{array}$ & & & & 0.866 & & \\
\hline $\begin{array}{l}\text { To meet people with similar } \\
\text { interests and hobbies }\end{array}$ & & & & 0.571 & & \\
\hline $\begin{array}{l}\text { Because my family and } \\
\text { friends tell me to do this }\end{array}$ & & 0.607 & & & & \\
\hline To travel with family and friends & & 0.606 & & & & \\
\hline
\end{tabular}




\section{EFA Results}

An EFA was conducted on the 17 motivator variables using a principal components factor analysis with Oblimin rotation and Kaizer normalisation. The factor analysis identified six distinct motivator factors as presented in Table 5. These six factors accounted for $69.25 \%$ of total variance. The Kaiser-Meyer-Olkin (KMO) measure of sampling adequacy was 0.636 which indicates an acceptable correlation. Bartlett's Test of Sphericity also indicated a statistical significance at $0.001(\mathrm{Df}=136)$.

The results presented in Table 5 show that there are six distinct motivator factors as perceived by the respondents at the Barberton Makhonjwa Geotrail.

Table 6. Component correlation matrix

\begin{tabular}{|c|c|c|c|c|c|c|}
\hline Factor & F1 & F2 & F3 & F4 & F5 & F6 \\
\hline F1 & 1.000 & .023 & .055 & .140 & -.242 & .243 \\
\hline F2 & .023 & 1.000 & -.008 & -.024 & -.027 & -.137 \\
\hline F3 & .055 & -.008 & 1.000 & .017 & -.129 & .027 \\
\hline F4 & .140 & -.024 & .017 & 1.000 & -.180 & .183 \\
\hline F5 & -.242 & -.027 & -.129 & -.180 & 1.000 & -.198 \\
\hline F6 & .243 & -.137 & .027 & .183 & -.198 & 1.000 \\
\hline
\end{tabular}

Table 6 provides an indication of the component correlation between the six identified factors. The factors identified have relatively low coefficients, indicating that these factors are distinct, have few relationships with one another, and can be considered significantly distinct. There is however a minor relationship between Factor 1 and Factor 6. The main motivator factor was identified as fun. This motivator factor included the variables of excitement and to have fun; it also scored the highest mean as well as the highest reliability coefficient. This finding indicates that respondents were primarily intrinsically motivated as described by Ryan and Deci (2000) and may be considered serendipitous geotourists (Hurtado et al., 2014). Thus, the main motivator to the Geotrail is not necessarily geology itself, and the majority of visitors may not be purposeful geotourists, but rather tourists who want to have fun.

This motivator factor was followed by the need for learning and novelty. According to Hurtado et al., (2014) this may imply a purposeful geotourist, or a traveller that visits the site for the primary purpose of learning about geotourism. This may also be considered an intrinsic form of motivation as identified by Ryan and Deci (2000).

Escape was identified as the third main reason for respondents to visit the site and matches the escape seeking geotourist as identified by Hose (2007). This form of autonomous motivation (Ryan \& Deci, 2000) may be both intrinsically motivated and extrinsically motivated. Thus, the respondent perhaps has a desire to get away from routine and to relax as the main intrinsic motivation, and the desire to visit the Geotrail may be the secondary motivation, which is extrinsic.

Personal importance aspects included the element of social, cultural and recreational advantages for the respondent and the belief that it is personally important to travel to the site. These intrinsic motivations indicate that these respondents are drawn to the site for recreational opportunities offered by the Geotrail.

Activities and networking fulfils the social desire of respondents who wish to spend time with people who have similar interests, either socially or in terms of activities. These respondents are also intrinsically motivated as described by Ryan and Deci (2000).

The motivator of family and friends was identified as the sixth motivator. However, due to a low reliability coefficient and the lowest mean, it cannot be considered a reliable measure of motivation for this study. This motivator was also the 
only one which stood out as a controlled motivation and may be considered a form of amotivaiton as identified by Allan (2011).

\section{CONCLUSIONS AND MANAGERIAL IMPLICATIONS}

Geotourism is a growing niche tourism market. As a result, geotourism has started to receive increased interest from researchers studying different aspects of this phenomenon. However, research into geotourism demand and motivation is somewhat scarce. The Barberton Makhonjwa Geotrail is a relatively new geotourism attraction in South Africa. As a geological site, it is well established due to its geological significance, but from a tourism point of view, it is comparatively novel.

Therefore, tourism related studies concerning this site are required for purposes of positioning it as a tourist attraction, as well as for the development of effective marketing and promotion strategies. To date, there is no information available regarding the people who are attracted to visit the Geotrail, nor what motivates them to visit. As a result, this study aimed to gain an understanding of the motivations of visitors that engage in a geotourism experience at this site.

Findings indicated that respondents were motivated to visit the Geotrail for five primary reasons, namely; to escape, to learn and for novelty, to participate in activities and networking, for fun, and lastly, for personal importance. All these motivator factors represent intrinsic motivation according to the SDT. One factor, namely family and friends, was identified as the sixth highest rated factor. However, it was not significant enough to warrant being listed as a main factor. This was also the only factor which was considered a controlled motivator as these respondents were effectively mandated to visit the Geotrail and did not do so at their own discretion. The local and provincial bodies responsible for managing and promoting the Barberton Makhonjwa Geotrail will need to take into account these key visitor motivations. Acknowledging such motivations will ultimately assist in determining the future development of products / services on the Geotrail (with a view to ensuring visitor satisfaction), in addition to the design of promotional activities that 'speak to' the primary motivations for visitation.

Opportunities for future research include the potential for a longitudinal study on the Barberton Makhonjwa Geotrail (given its infancy), to document trends and patterns in visitor characteristics and motivations over time. In the event of the Barberton Makhonjwa Geotrail being awarded UNESCO World Heritage Status, this could also present a further research opportunity in terms of the impact of its new status on visitation. Cross-border comparisons with other geotrails is also permissible.

Furthermore, unlike other previous studies such as Hurtado et al. (2014), this study did not aim to measure whether the existence of the Barberton Makhonjwa Geotrail serves as a catalyst for tourism to the wider destination; in this instance Barberton, or the Mpumalanga province itself. Thus, there is potential for future research in this regard.

\section{Acknowledgement}

The authors would like to thank all the 2017 BTech Tourism Management students of the Tshwane University of Technology Mbombela campus for their effort in the data collection for this study.

\section{REFERENCES}

Allan, M. (2011). Toward a better understanding of motivations for a geotourism experience: a selfdetermination theory perspective. D. Phil. thesis, Perth, Edith Cowan University.

Allan, M., Dowling, R.K., \& Sanders, D. (2015). The motivations for visiting geosites: the case of Crystal Cave, Western Australia. GeoJournal of Tourism and Geosites, 2(16):142-153. 
Allan, M. (2016). Exploring the potential for geotourism development in the United Arab Emirates. International Journal of Tourism and Hospitality Research, 27(3):401-404.

Amrikazemi, A., \& Mehrpooya, A. (2006). Geotourism resources of Iran in Geotourism. In: Dowling, R. \& Newsome, D. (eds.). Geotourism. Oxford: Elsevier Butterworth-Heinemann: 78-92.

Burne R., \& Chapple, R. (2008). Under the boardwalk - tourism's encounters with stromatolites. Addressing the issues of stromatolite protection and visitor management. In Dowling R, Newsome D (eds). Inaugural Global Geotourism Conference Australia 2008 'Discover the Earth Beneath our Feet' Conference Proceedings. Promaco Conventions: Perth; 107-112.

Cohen, E. (1972). Towards a Sociology of International Tourism. Social Research, 39(1):164-182.

Dann, G. (1981). Tourist motivation: an appraisal. Annals of Tourism Research, 8(1):187-219.

Deci, E.L., \& Ryan, R.M. (2008). Self-determination theory: a macrotheory of human motivation, development and health. Canadian Psychology, 49(3):182-185.

Dowling, R., \& Newsome, D. (2006). Geotourism. In: Dowling, R. \& Newsome, D. (eds.). Geotourism. Oxford: Elsevier Butterworth-Heinemann: 4-6.

Farsani, N.T., Coelho, C. \& Costa, C. (201)1. Geotourism and geoparks as novel strategies for socio-economic development in rural areas. International Journal of Tourism Research, 13:(1):68-81.

Farsani, N.T., Mortazavi,M., Bahrami, A., Kalantary, R., \& Bizhaem, F.K. (2017). Traditional Crafts: a Tool for Geo-education in Geotourism. Geoheritage, 9(4):109-114.

Ferrar, T., \& Heubeck, C. (2013). Barberton-Makhonjwa Geotrail: geosites and viewpoints. Mbombela: Hamilton-Fynch.

Gagne, M., \& Deci, E. (2005). Self-determination theory and work motivation. Journal of Organisational Behaviour, 26(4): 331-362.

Harrill, R., \& Potts, T.D. (2002). Social psychology theories of tourist motivation: exploration, debate and transition. Tourism Analysis, 5(1):105-114.

Hose, T.A. 5(199). Selling the story of Britain's Stone. Environmental Interpretation, 10(2):16-17.

Hose, T.A. (2007). Geotourism in Almeria province south east Spain. Tourism, 55(3):259-276.

Hose, T. A. (2012). 3G's for Modern Geotourism. Geoheritage, 4(1-2):7-24.

Hurtado, H., Dowling, R., \& Sanders, D. (2014). An exploratory study to develop a geotourism typology model. International Journal of Tourism Research, 16(6):608-613.

Kim, S.S., Kim, M., Park, J., \& Guo, Y. (2008). Cave Tourism: Tourists' Characteristics, Motivations to Visit, and the Segmentation of Their Behavior. Asia Pacific Journal of Tourism Research, 13(3):299-318.

King, L.M. (2010). Geotourism in the Hawaiian Islands. In: Newsome, D. \& Dowling, R.K. (eds.). Geotourism: the tourism of geology and landscape. Oxford: Goodfellow publishers:114-125.

Mao, I., Robinson, A.M., \& Dowling, R. (2009). Potential geotourists: an Australian case study. Journal of Tourism, 10(1):71-80.

McKercher, B. (2002). Towards a classification of cultural tourists. Journal of Tourism Research, 4(1):29-38.

McIntosh, R. W., Goeldner, C. R., \& Ritchie, J. R. B. (1995). Pleasure travel motivation. In: McIntosh, R. W., Goeldner, C. R. and Ritchie, J. R. B. Eds. Tourism: principles, practices, philosophies. pp.167-190.

Norrish, L., Sanders, D., \& Dowling, R. (2014). Geotourism product development and stakeholder perceptions: a case study of a proposed geotrail in Perth, Western Australia. Journal of Ecotourism, 13(1):52-63.

Plog, S. (1974). Why destination areas rise and fall in popularity. Cornell Hotel and Restaurant Quarterly, 14(40):55-58.

Ruban, D.A. (2015). Geotourism - A geographical review of the literature. Tourism Management Perspectives, 15(1):1-5.

Ryan, R.M., \& Deci, E.L. (2000). Intrinsic and extrinsic motivations: classic definitions and new directions. Contemporary Educational Psychology, 25(1):54-67.

Sadry, B.N. (2009). Fundamentals of Geotourism: with emphasis on Iran. Available: Online at: http://https://journals.openedition.org/physio-geo/4873?file=1 [Accessed: 30 April 2018].

Wrede, V., \& Mügge-Bartolović. (2012). GeoRoute Ruhr-a Network of Geotrails in the Ruhr Area National GeoPark, Germany. Geoheritage, 4(1-2):109-114.

Zouros, N.C. (2010). Lesvos Petrified Forest Geopark, Greece: Geoconservation, Geotourism, and Local Development. The George Wright Forum, 27(1):19-28

*** Barberton Tourism \& Biodiversity Corridor (BATOBIC). (2018). The Barberton Makhonjwa Geotrail. [online].

*** United Nations Education, Scientific and Cultural Organisation (UNESCO). (2018). Barberton Makhonjwa Mountains. [online]. Available at: https://whc.unesco.org/en/list/1575 [Accessed 31 October 2018].

Submitted:

15.09.2018
Revised:

29.03.2019
Accepted and published online

01.04.2019 